\title{
Is fish passage technology saving fish resources in the lower La Plata River basin?
}

\author{
Norberto Oscar Oldani*, Claudio Rafael Mariano Baigún**, \\ John Michael Nestler*** and Richard Andrew Goodwin***
}

Over 450 dams have been constructed in the upper Paraná River basin in Brazil during the past 40 years. River regulation by these dams is considered a primary factor in the reduction of fish diversity and depletion of migratory species. In contrast to the upper Paraná Basin, only two large dams (both with upstream fish passage) have been constructed in the lower La Plata River basin. Fishery managers in the lower basin are concerned that existing and planned dams will further deplete populations of migratory fish species that constitute important recreational and commercial fisheries as has occurred in the upper basin. We assessed the sustainability of fisheries in the lower basin in the face of increased river regulation by using literature information to describe the efficiency of the fish passage systems used to mitigate river regulation impacts on fisheries. Our analysis shows that fish passage systems at both lower basin dams, Yacyreta and Salto Grande, fail to transfer sufficient numbers of upstream migrants to sustain populations of migratory species. Fish passage efficiency of target species in the fish elevators at Yacyreta is less than $2 \%$. Fish diversity in the fish elevators is low because about $85 \%$ of the fish belong to only three nonmigratory species (Pimelodus maculatus, Oxydoras kneri and Rhinodoras dorbignyi). Large migratory species targeted for passage rarely comprise even $5 \%$ of the fish number in the passage system. The two Borland locks at Salto Grande Dam cannot dependably pass large numbers of migratory species because passage efficiency is dependent upon interactions of powerhouse and spillway operation with tailrace elevations. Most species in the Borland system were either a small catfish (Parapimelodus valenciennis) or a engraulid (Lycengraulis grossidens). Again, the targeted migratory species were not abundant in the passage system. We conclude that existing fish passage technology in the lower basin is inadequate and that improved fish passage designs are required to conserve migratory species. These designs must be based on integrated information from geomorphology (habitat), natural fish behavior, fish swimming capabilities, and detailed population studies.

Mais de 450 barragens foram construídas no alto rio Paraná, Brasil, nos últimos 40 anos. A regulação dos rios por barragens é considerada um dos fatores primários de redução da diversidade de peixes e depleção de espécies migratórias. Em contraste, somente duas grandes barragens foram construídas nos trechos mais inferiores da bacia do rio da Prata. No momento, há uma grande preocupação acerca do impacto dos represamentos sobre espécies que se constituem a base da pesca comercial e esportiva na bacia. Este artigo aborda o desempenho das passagens de peixes das barragens de Yacyreta e Salto Grande, monstrando que as mesmas falham na transferência de grandes quantidades de espécies migratórias para os trechos a montante. A barragem de Yacyreta tem dois elevadores com problemas importantes de projeto. Como resultado, a eficiência na passagem das espécies-alvo é menor do que $2 \%$. A diversidade das espécies transferidas é baixa, uma vez que $85 \%$ dos espécimes dominantes nos elevadores foram representadas por uma espécie de Pimelodidae (Pimelodus maculatus) e duas de Doradidae (Oxydoras kneri e Rhinodoras dorbignyi). A passagem de grandes espécies alvo migratórias raramente compreende até $5 \%$ do número de peixes no sistema de passagem. A barragem de Salto Grande tem duas passagens do tipo eclusas de Borland linstaladas, cuja performance varia consideravelmente dependendo da operação da casa de força e dos vertedouros, bem como da elevação de nível no canal de fuga. A maioria dos espécimes que passam pertencem a uma pequena espécie de Pimelodidae (Parapimelodus valenciennis) e a uma espécie de Engraulidae (Lycengraulis grossidens). Um novo direcionamento no desenho de passagens de peixes é necessário para a preservação das espécies migratórias em rios Sul Americanos. Informações integradas de geomorfologia (habitat), atratores de natureza hidrodinâmica detectável pelos peixes para selecionar as rotas de migração ascendentes e descendentes, capacidade natatória dos peixes e estudos detalhados de populações são necessárias.

Key words: Non salmonid species, Migratory fish, Yacyreta Dam, Salto Grande Dam.

\footnotetext{
*Instituto de Desarrollo Tecnológico para la Industria Química (INTEC-CONICET-UNL), Güemes 3450, S3000 Santa Fe, Argentina. gbio@ceride.gov.ar

**Instituto Tecnológico de Chascomús, (IIB-INTECH), Camino de Circunvalación Laguna, Km 6, 7130 Chascomús, Argentina. claudiobaigun@intech.gov.ar

***U.S. Army Engineer Research \& Development Center, Vicksburg, MS, USA. john.m.nestler@erdc.usace.army.mil
} 


\section{Introduction}

Large river impoundments provide flood control, create recreation opportunities, generate hydropower, provide water supply, support inland navigation, and generally support economic development in many other ways. Dam building has experienced considerable growth around the world over the last five decades (Petts, 1990) because of these benefits. As of 1998, 979 dams were located in South America with 646 occurring in Brazil (World Commission on Dams, 2000). Fifty of the dams have the sole purpose of generating hydropower and impound reservoirs covering a total area over $8000 \mathrm{~km}^{2}$ (Sugunan, 1997). At present, 90\% of Brazil's electric power is generated by hydroturbines and $70 \%$ is generated in the Paraná basin (Petrere et al., 2002). In the upper Paraná basin in Brazil, 452 dams have been constructed (Paiva, 1982, cited by Okada et al., 1996) of which 90 create impoundments larger than $100 \mathrm{~km}^{2}$.

River regulation in the upper La Plata River basin has significant environmental impacts and is considered to be one of the primary factors reducing fish diversity (Agostinho \& Gomez, 1997). Dams in the upper basin fragment the waterscape both by creating a physical barrier to longitudinal movement and by disrupting lateral connectivity by reducing the flood pulse. Many fish species have sequential life stages with each requiring a different geo-form (e.g., secondary channels, lagoons, floodplains and main channels). They also require that these different geo-forms be seasonally connected by a substantial and reasonably reliable flood pulse (Junk et al., 1989). In contrast, the lower portion of the basin still contains long unregulated reaches where the alluvial valley is still dynamically connected to the main channel. Only two large dams occur in Argentina, although there are several projects planned for the Middle Paraná and Uruguay Rivers.

Fish passage technology can be used to help mitigate some of the impacts of river regulation. Relatively few of the large numbers of dams in the upper basin have fish passage facilities with Clay (1995) mentioning about 50 with most being low head, pool and weir fishways (Quirós, 1988). Systems more appropriate for higher head dams (e.g., locks, elevators, bypass channels ) are located at Salto Grande (Uruguay River), Yacyretá and Puerto Primavera (Paraná River), Santa Clara (Mucuri River), Funil (Grande River), and Itaipu (Paraná River).

The rivers of the La Plata basin, like all of the great rivers of South America, support a diverse ichthyofauna of large, migratory fish that have a potadromous life-history strategy. These fishes represent $21 \%$ of fish abundance in rivers with floodplains (Agostinho et al., 2000; Agostinho et al., 2003). They are well adapted to the geomorphology of the valley and seasonal pattern of the flood pulse with different lifestages predictably migrating at specific periods of the year (Oldani, 1990). Migrations vary in distance, direction, and time of year depending on species and basin (Petrere, 1985). Migrations are triggered by climatic and hydrological cues (Vazzoler et al., 1997), and the stimulus for the onset of migration for each species seems to be similar in the lower and upper basin (Agostinho et al., 2003). Some species such as Prochilodus lineatus (sabalo), Salminus brasiliensis (dorado), Leporinus obtusidens (boga), Luciopimelodus pati (pati), Pseudoplatystoma corruscans, (surubí pintado), Pseudoplatystoma fasciatum (surubí atigrado), Piaractus mesopotamicus (pacú) and Zungaro jahu (manguruyú; the species from La Plata drainage has been long referred as a synonym of Zungaro zungaro but it is a valid species and distinct from $Z$. zungaro from the Amazon) are capable of making long migrations (Bayley, 1973; Bonetto, 1986; Tablado \& Oldani, 1984; Delfino \& Baigún, 1985; Espinach Ros et al., 1998; Sverlij et al., 1993).

The goal of this paper is to critically evaluate the performance of existing fish passage systems at two large dams (Yacyretá and Salto Grande) used to mitigate impacts on migratory fish in the lower La Plata River basin. The evaluation allows us to determine if existing fish passage technology is adequate to help conserve the iconic, large migratory fishes of the La Plata Basin at these dams as well as at future dams planned for the lower basin. It will also allow us to identify target areas where research and development are needed to improve these systems to help ensure the development of sustainable water resources in the La Plata basin.

\section{Material and Methods}

Yacyretá Dam, located in the upstream end of the middle Paraná (Argentina-Paraguay), has a nominal height of $21 \mathrm{~m}$ (Fig. 1), a mean annual discharge of $12,000 \mathrm{~m}^{3} \mathrm{~s}^{-1}$, and impounds a reservoir of $1,600 \mathrm{~km}^{2}$. The powerhouse contains 20 Kaplan turbines with a total generating capacity of 20,000 GWH and a combined maximum discharge of $16,000 \mathrm{~m}^{3} \mathrm{~s}^{-1}$. Fish passage facilities at Yacyretá Dam consist of two elevators located in the main channel powerhouse that began operation in 1995. The dam design includes provision for two additional elevators at a secondary powerhouse that is under construction. The fish passage system also includes attraction (collection) channels with entrance gates on the face of the powerhouse. The collection channels are $3 \mathrm{~m}$ deep and 4 $\mathrm{m}$ wide with the left channel having a length of $70 \mathrm{~m}$ and the right channel having a length of $109 \mathrm{~m}$. A fish elevator is located at the upstream end of each channel furthest from its entrance gate. Each channel also has a movable crowder screen which, when not operating, is located about $15 \mathrm{~m}$ downstream of the elevators. Operation of each elevator begins with movement of the mechanical screen to crowd fish into the single elevator. Each elevator has a capacity of $15 \mathrm{~m}^{3}$ and requires approximately $7 \mathrm{~min}$ travel time from the collectionchannel entrance level to the forebay exit level. Once each elevator is at the exit level, it is tipped into a gated chute where fish can either be released into the reservoir or diverted to a temporary holding tank for sampling. After the elevator is emptied, it is returned to its upright position, refilled with water for counter balancing, and returned to the level of the collection channel to begin the next cycle. Basic information describing the dam, operation of the fish pas- 


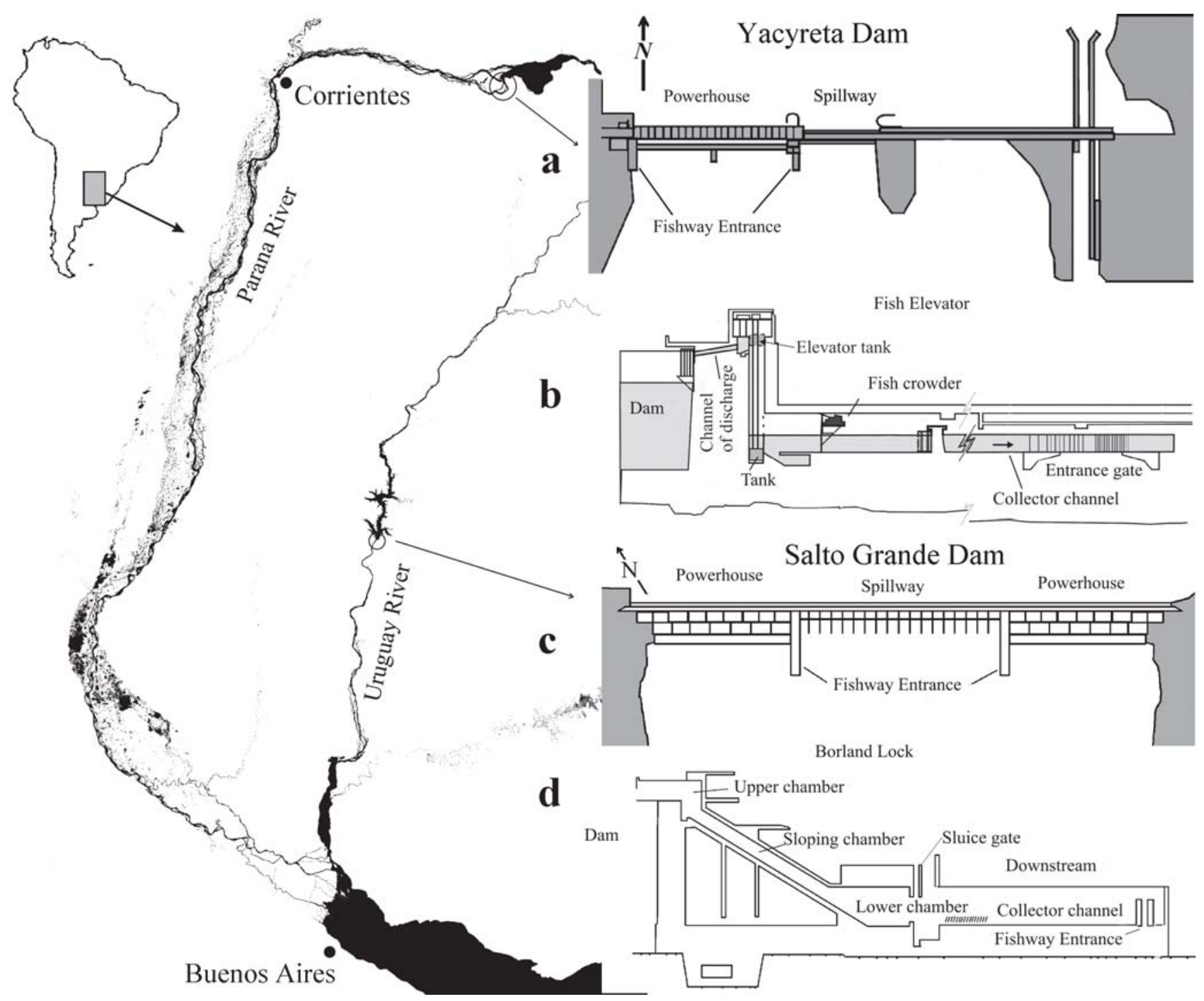

Fig. 1. Geographic location of Yacyretá Dam (Parana River) and Salto Grande Dam (Uruguay River) and fishway details. Location map and project features for Yacyreta and Salto Grande dams.

sage system, and passage efficiency was consolidated from Oldani et al. (2001a, 2005a), Roncatti et al. (2000, 2001), and Oldani and Baigún (2002).

Salto Grande Dam was put into operation in 1979, but the fish locks were not operational until 1984. This dam (Fig. 1), located in the middle Uruguay River, has a nominal height of $30 \mathrm{~m}$, impounds a reservoir of $800 \mathrm{~km}^{2}$, and has a mean annual discharge of 4,600 $\mathrm{m}^{3} \mathrm{~s}^{-1}$. Its powerhouse contains 14 Kaplan turbines with a combined discharge of $9800 \mathrm{~m}^{3} \mathrm{~s}^{-1}$, having a water velocity at the tailrace of $2.8 \mathrm{~m} \mathrm{~s}^{-1} \mathrm{Hydraulic}$ residence time of the impoundment is only 12 days. The passage system features two Borland fish locks, one on each side of the spillway, and an associated attraction channel having a flow velocity of $0.9 \mathrm{~m}^{3} \mathrm{~s}^{-1}$. Each lock is comprised of a slanted, closed conduit that links the downstream river (through an attraction channel) with the upstream reservoir. A lock gate controls water flow and fish movement at each end of the conduit. An attraction flow of about $0.5 \mathrm{~m} / \mathrm{s}$ is used to en- courage fish to enter the lock. A passage cycle begins with the upper gate closed to prevent entry of forebay water and the lower gate opened to allow fish entry into the lock. The lower gate is then closed and water fills the system until the water level within the lock is approximately the same as the forebay water level. The upper gate is then opened to allow fish to enter the impoundment. The upper gate is then closed and water is drained from the lock until the lower gate can be opened to start the next cycle. A transfer cycle typically takes about $55 \mathrm{~min}$. Basic information describing Salto Grande Dam, its operation, and passage efficiency was consolidated from Delfino et al. (1986), CARU-CTMSG-INAPE-INIDEP (1994), Espinach Ros et al. (1997), Leites (1999), Oldani \& Leites (2001); Oldani et al. $(2002,2005$ b). We also present results from tailwater acoustic surveys performed in November of 2000 and 2002 using a Simrad EQ500 echosounder with a $200 \mathrm{kHZ}$ split beam transducer. These surveys were conducted to relate tailwater fish concentrations to the attraction channel entrance loca- 
tions. Water velocity was measured using plastic buoys provided with a GPS system.

\section{Results}

General characteristics, including design limitations, about the fish passage systems at the two dams is summarized in Table 1 and described in detail below.

\section{Yacyretá Dam}

A total of 78 fish species were collected in the tailwater of which $68 \%$ were also collected in the elevators. However, elevator samples were dominated by a couple of non-migratory species. Pimelodus maculatus was consistenly most abundant in the elevator samples ( $73 \%$ by number and $45 \%$ by biomass) followed by Pterodoras granulosus (12\% by number and $25 \%$ by biomass) (Fig. 2). The targeted large, migratory species comprised only $5-7 \%$ of fish abundance in the elevators, whereas they comprised $30 \%$ of the tailwater fish assemblage (Oldani \& Baigún 2002) (Fig. 3). Prochilodus lineatus was the most abundant migratory fish sampled in

Table 1. Primary fishway characteristics at Yacyreta and Salto Grande dams.

\begin{tabular}{|c|c|c|}
\hline Characteristic & Yacyreta & Salto Grande \\
\hline $\begin{array}{l}\text { Species richness in } \\
\text { tailwater }\end{array}$ & high & moderate \\
\hline $\begin{array}{l}\text { Knowledge of migratory } \\
\text { species bionomics } \\
\text { patterns }\end{array}$ & poor & poor \\
\hline $\begin{array}{l}\text { Hydrodynamic variables } \\
\text { affecting migration } \\
\text { behavior }\end{array}$ & not available & not available \\
\hline Fishway fish diversity & low & low \\
\hline $\begin{array}{l}\text { Fishway efficiency for } \\
\text { migratory species }\end{array}$ & low & unknown \\
\hline $\begin{array}{l}\text { Most frequently passed } \\
\text { species }\end{array}$ & non migratory & non migratory \\
\hline $\begin{array}{l}\text { Fishway mechanical } \\
\text { problems }\end{array}$ & yes & no \\
\hline Design limitations & small elevators size & $\begin{array}{l}\text { narrow collector } \\
\text { channel gates }\end{array}$ \\
\hline Cycle number limitation & yes & no \\
\hline Entrance location & $\begin{array}{l}\text { Too close to turbine } \\
\text { discharges }\end{array}$ & facing spillways \\
\hline Attraction flows & $\begin{array}{l}\text { masked by turbine } \\
\text { discharge }\end{array}$ & $\begin{array}{l}\text { only detectable when } \\
\text { spillway is closed }\end{array}$ \\
\hline $\begin{array}{l}\text { Capacity for downstream } \\
\text { passing }\end{array}$ & no & no \\
\hline $\begin{array}{l}\text { Possibility of injury } \\
\text { during passage }\end{array}$ & $\begin{array}{l}\text { High due to crowding } \\
\text { of armored fish }\end{array}$ & Not detected \\
\hline $\begin{array}{l}\text { Contribution to fisheries } \\
\text { improvement }\end{array}$ & Not detected & not detected \\
\hline Fishway exits & $\begin{array}{l}\text { to close to turbine } \\
\text { entrances }\end{array}$ & appropriate \\
\hline
\end{tabular}

the elevator (Fig. 4). This pattern of fish passage was consistent over the study period (1995-2001), leading us to conclude that the Yacyretá elevators are unable to pass sufficient numbers of the target species to maintain sustainable population numbers. We estimated passage efficiency for large migatory fish at 1.88\% for the period of 1995-1998 (Oldani \& Baigún, 2002), a value lower than the $7 \%$ predicted by Collin (1997) in his assessment of the mitigation performance of World Bank funded projects. Although Yacyretá elevators were able to pass thousands of fishes (Roncati et al., 2001), they failed to transfer sufficient numbers of the targeted, highvalue migratory species. The poor performance of the fish elevators for conserving large migratory species was also reflected in the experimental design of studies by Makrakis et al. (2002). They were able to collect and tag only a few specimens of the large migratory species (P. lineatus, Salminus. brasiliensis and P. corruscans) at several sites in the Paraná River upstream of Yacyretá and in the Yacyretá elevators.

Roncati et al. $(2000,2001)$ showed similar species composition in his studies of the Yacyretá Dam fish elevators. He also noted that the two collection channels exhibited differ-

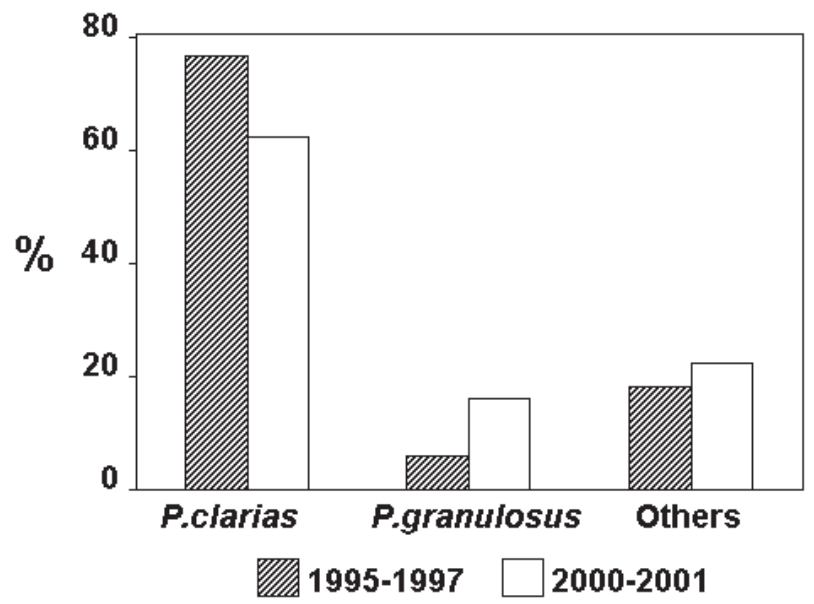

Fig. 2. Species composition of fishes sampled in the Yacyreta elevators. Data from 1995-1997 adapted from Oldani et al., (2002) and from 2000-2001 adapted from Roncati et al. $(2000 ; 2001)$.

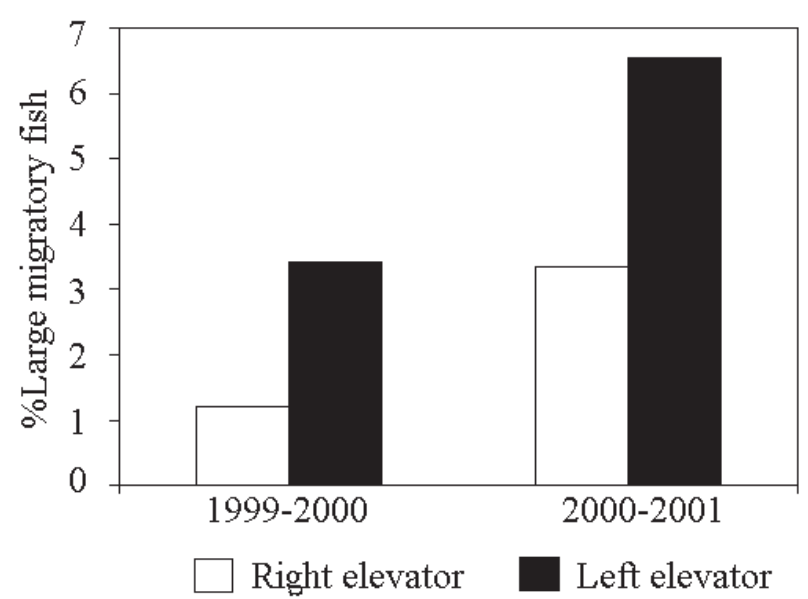

Fig. 3. Percentage of target species in the right and left elevators in Yacyreta Dam. 
ent water velocities. Average water velocity in the right collection channel was $0.22 \mathrm{~m}^{3} \mathrm{~s}^{-1}$, but $0.39 \mathrm{~m}^{3} \mathrm{~s}^{-1}$ in the left collection channel. By analyzing data reported in Roncati et al (2001), we note that water velocities progressively increase from the channel entrance to the crowder (Fig. 5). The results of fish acoustic surveys in the tailwater showed that fish concentration was greatest in the original channel thalweg downstream from the navigation locks (Fig. 6) where depth is $16 \mathrm{~m}$ depth with mean water velocity less than $0.5 \mathrm{~ms}^{1}$. We also note that most fish preferred the right channel margin instead of the area near the fish passage entrances.

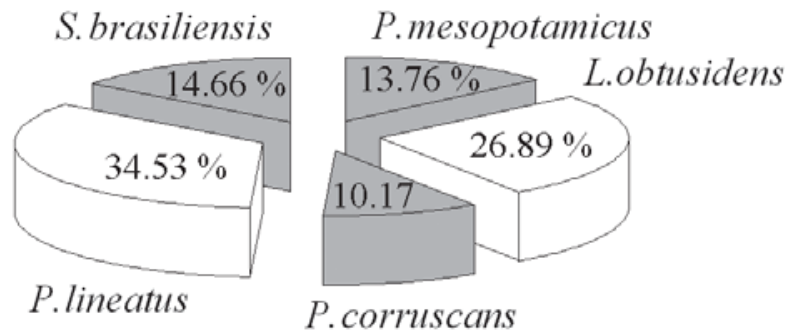

Fig. 4. Percent composition for important migratory fish species sampled in the Yacyreta elevators including dorado (Salminus brasiliensis), sábalo (Prochilodus lineatus), pacu (Piaractus mesopotamicus), boga (Leporinus obtusidens), and surubi (Pseudoplatystoma corruscans and P. fasciatum).

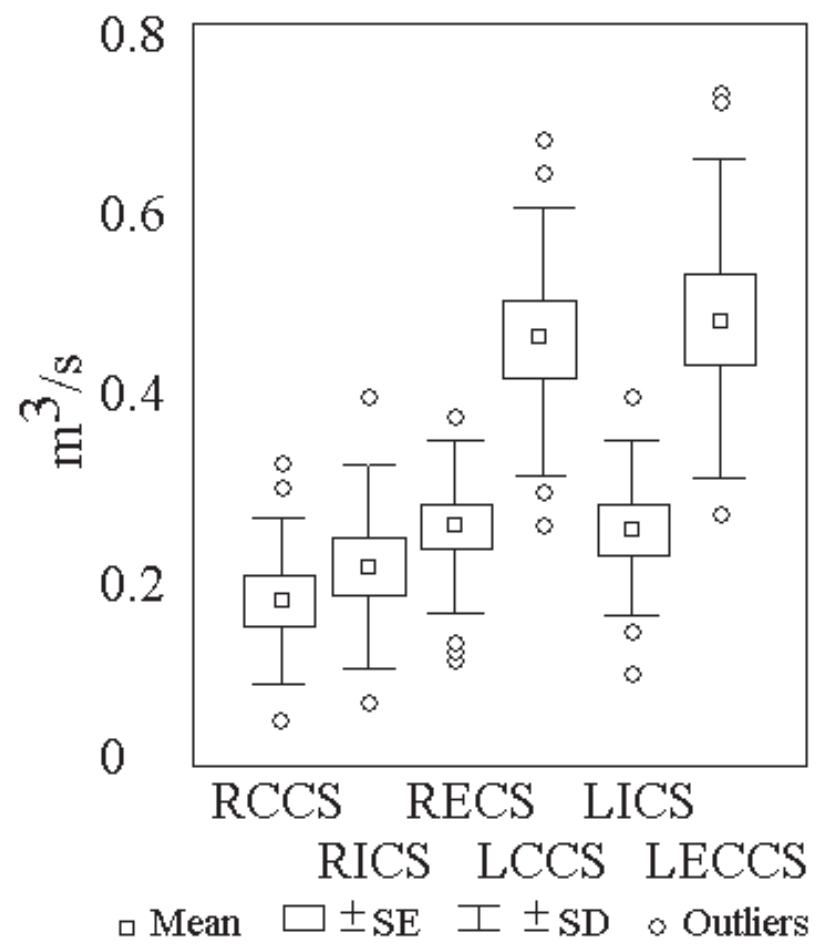

Fig. 5. Water velocities in right and left collection channels of the Yacyreta fish passage system. RCCS: Right crowder channel section; RICS: right intermediate channel section; RECD: right entrance channel section; LCCS: left crowder channel section; LICS: left intermediate channel section; LECS: left entrance channel section.

\section{Salto Grande Dam}

A total of 48 fish species were collected in the tailrace and Borland locks (Espinach Ros et al., 1997) and 36 fish species were collected in the locks (Table 2). Trap collections at the upper chamber exit gate indicated that Auchenipterus nuchalis, Parapimelodus valenciennis and Lycengraulis grossidens were the dominant species utilizing the passage system. Target migratory species such as S. brasiliensis, $L$. obtusidens and P. lineatus were sporadically observed and giant catfishes in the genera Pseudoplatystoma and Zungaro, although collected in the tailrace, were rarely observed in the locks (Fig. 7). The percentage of species collected in both the tailrace and the lower chamber varied greatly among sampling periods (Fig. 8). Species compositions in the lower and upper chambers were in close agreement over the years, suggesting that fish entering the lock have a high probability of reaching the upper chamber. We also note that percentage of species found in coincident samples in the tailrace and lock chambers was low indicating substantial species selectivity by the locks. Fish occurred in the attraction channel at all tested flows, but the greatest passage to the upper chamber occurred when flows are 0.5 to $1.5 \mathrm{~m}^{3} \mathrm{~s}^{-1}$ (Fig. 9).

Qualitative observations about fish migration behavior observed shortly after closure are valuable because they provide information about the natural behaviors of fish populations (Delfino et al., 1986). After river closure, large numbers of fishes were observed in the tailrace attempting to migrate, primarily during March-April and September-October (Delfino \& Baigún, 1985) coincident with the primary spring flood pulse and the secondary fall hydrograph peak of the Paraná River.

Different species may exhibit different migration behaviors that can affect lock efficiency. Species such as $P$. lineatus and L. obtusidens are thought to parallel the shore line until they reach the powerhouse discharge zone because they are commonly captured in shoreline samples. Those fish that reach the spillway area (when the spillways are closed) may locate and enter the collection channel. Other species, such as $S$. brasiliensis, are captured in the powerhouse turbine discharge zone but are not captured in shoreline samples indicating that they likely follow the thalweg to the powerhouse discharge zone. This pattern of near-shore versus thalweg migration route was confirmed by acoustic surveys conducted during the spring of 2002 migration. We detected the highest fish densities on the landside of the powerhouse discharge zone at a depth of 7-11 $\mathrm{m}$ in water velocities between 0.5 and $1.0 \mathrm{~m}^{3} \mathrm{~s}^{-1}$ when the spillway was operating and lower densities in this zone when the spillway was closed (Fig. 10).

\section{Discussion}

Concepts about fish migration and passage are dominated by the well-studied salmonids of the Northern Hemisphere. However, the large migratory fishes of South America exhibit important differences from salmonids (Oldani et al., 2005a) that must be considered in their sustainable management: 
almost all are potadromous; they are iteroparous and typically make several spawning migrations during their lifetime; and they use floodplains as hatching areas (Oldani et al., 1998). Case histories describing the performance of fish passage systems in Latin America are both scarce and inconclusive.

According to Larinier (2001), the objectives of upstream fish passages are to attract migrants to a specified point in the river downstream of the obstruction and to induce them to pass upstream. While fish passage principles are simple in concept, performance evaluation of passage systems has been a source of debate. García (1999), for example, claimed that Yacyretá Dam fishways provide adequate genetic exchange among downstream and upstream populations, but without specifying the minimum passage required to prevent genetic isolation. Although, the minimum required passage is still unknown, passage rates at the lower basin dams are low for target migratory species so that the claim of adequate genetic exchange must be supported. As an additional challenge to successful upstream passage, the high abundance and diversity of fishes in tailraces can easily overwhelm existing, under-sized adult passage systems so that target species are either crowded out or damaged by their close proximity to armored species in the confines of the passage system. For example, Quirós et al. (2000) acknowledge the presence of 18 priority species in the Lower La Plata basin that should be considered for dam passage, but the total number of migratory species identified in South American rivers may be as high as 70 (Carolsfeld et al., 2004). Also, existing fish passage system cannot be considered the only management approach for maintaining upstream biodiversity because the lentic characteristics of the forebay has a substantial impact on a fish community evolved for lotic environments.

Passage systems may be based on a number of alternative configurations (Table 3), but many fish passage innovations and advances were designed to conserve salmonids. (Clay, 1995; Odeh 1999, 2000). Pool and weir systems (ladders) are common in northern hemisphere rivers (Cada \& Sale 1993), and it is, therefore, not surprising to find such systems dominating fish passage designs on the Paraná River in Brazil. Godoy (1985) indicates that more than 20 such systems were built on small dams in northeastern Brazil and primarily pass adults of Prochilodus scrofa ( $=$ P. lineatus - curimbatá), Leporinus copelandii, L. octofasciatus, L. elongatus $S$. brasiliensis, Salminus hilarii (dorado plateado) and $P$. maculatus. He observed that most fishes used the ladder when attraction water velocity ranged from $0.5 \mathrm{~m}^{3} \mathrm{~s}^{-1}$ to $2.5 \mathrm{~m}^{3}$ $\mathrm{s}^{-1}$. Godoy (1975) also mentioned that about 50,000 adults of P. lineatus were transferred per day in the Cachoeira de Emas ladder, but warned that only systems installed on dams lower than $16 \mathrm{~m}$ high appeared to be effective. At the same dam, Capeleti and Petrere (2006) reported that P. lineatus was more attracted by adjacent impassable spillways than by the ladder itself indicating that even in low-head dams, hydraulic patterns can strongly affect passage efficiency. At Igarapava Dam, P. lineatus, $P$. maculatus, Leporinus friderici and $L$. octofasciatus were identified as primary species using the fish ladder (Bowen et al., 2006). The 10-m high, 75-m long fish ladder at Salto Morais Dam on the Tijuco River was highly selective with only about $2 \%$ of fish ( 15 species) in the tailrace able to reach the higher sections of the fish ladder (Godinho et al., 1991). Another design, the experimental fish ladder (27 m high; $155 \mathrm{~m}$ long; and with a water velocity of 1.2 $\left.\mathrm{m}^{3} \mathrm{~s}^{-1}\right)$ at Itaipu Dam, was entered by 28 species including the migratory species P. lineatus, P. maculatus, and Leporinus

Table 2. Recorded species at the tailrace, lower chamber and upper chamber in Borland locks. J: January, 1993; M: March, 1994; A: April, 1994 (adapted from Espinach Ros et al., 1997).

\begin{tabular}{|c|c|c|c|}
\hline Species & Tailrace & $\begin{array}{c}\text { Lower } \\
\text { chamber }\end{array}$ & $\begin{array}{c}\text { Upper } \\
\text { chamber }\end{array}$ \\
\hline \multicolumn{4}{|l|}{ Siluriformes } \\
\hline Ageneiosus inermis & $\mathrm{J}$ & & \\
\hline Ageneiosus militaris & JMA & M & \\
\hline Auchenipterus nuchalis & $\mathrm{J}$ & JMA & JMA \\
\hline Hypostomus sp. & EMA & EMA & MA \\
\hline Iheringichthys labrosus & $\mathrm{J}$ & JMA & JMA \\
\hline Loricaria sp. & $\mathrm{M}$ & M & \\
\hline Loricariichthys anus & $\mathrm{E}$ & & \\
\hline Luciopimelodus pati & JMA & M & M \\
\hline Megalancistrus parananus & EMA & M & \\
\hline Megalonema platanum & & $\mathrm{JM}$ & $\mathrm{JM}$ \\
\hline Paraloricaria vetula & E & & \\
\hline Parapimelodus valenciennis & $\mathrm{J}$ & JMA & JMA \\
\hline Pimelodella sp. & & JMA & M \\
\hline Pimelodus maculatus & $\mathrm{J}$ & JMA & M \\
\hline Pseudoplatystoma corruscans & JMA & & \\
\hline Pterodoras granulosus & JA & $\mathrm{M}$ & \\
\hline Rhinelepis aspera & EM & M & \\
\hline Rhinodoras dorbignyi & JM & VMA & M \\
\hline Sorubim lima & $\mathrm{J}$ & $\mathrm{M}$ & \\
\hline Steindachneridion scriptum & JMA & & \\
\hline Trachelyopterus galeatus & $\mathrm{J}$ & M & M \\
\hline Zungaro jahu & $\mathrm{M}$ & & \\
\hline \multicolumn{4}{|l|}{ Characiformes } \\
\hline Apareiodon affinis & $\mathrm{J}$ & & \\
\hline Astyanax sp. & $\mathrm{E}$ & EA & EMA \\
\hline Charax stenopterus & & A & A \\
\hline Cynopotamus argenteus & $\mathrm{E}$ & EMA & EMA \\
\hline Cyphocharax platanus & $\mathrm{E}$ & & \\
\hline Leporinus obtusidens & EMA & EM & EM \\
\hline Oligosarcus hepsetus & & A & A \\
\hline Prochilodus lineatus & EMA & M & MA \\
\hline Pygocentrus nattereri & EM & & \\
\hline Rhaphiodon vulpinus & $\mathrm{E}$ & MA & MA \\
\hline Salminus brasiliensis & EM & EM & \\
\hline Schizodon nasutus & $\mathrm{E}$ & M & \\
\hline Schizodon platae & $\mathrm{E}$ & A & \\
\hline Serrasalmus spilopleura & EM & & \\
\hline \multicolumn{4}{|l|}{ Clupeiformes } \\
\hline Lycengraulis grossidens & $\mathrm{J}$ & JMA & JMA \\
\hline Pellona flavipinnis & $\mathrm{J}$ & M & M \\
\hline Ramnogaster melanostoma & & A & \\
\hline \multicolumn{4}{|l|}{ Gymnotiformes } \\
\hline Eigenmannia virescens & $\mathrm{J}$ & JMA & JMA \\
\hline Gymnotus sp. & & & M \\
\hline Rhamphichthys hahni & & M & M \\
\hline \multicolumn{4}{|l|}{ Perciformes } \\
\hline Pachyurus bonariensis & $\mathrm{J}$ & JMA & $\mathrm{J}$ \\
\hline \multicolumn{4}{|l|}{ Atheriniformes } \\
\hline Odontesthes sp. & & MA & A \\
\hline \multicolumn{4}{|l|}{ Rajiformes } \\
\hline Potamotrygon sp. & MA & MA & \\
\hline \multicolumn{4}{|l|}{ Pleuronectiformes } \\
\hline Catathyridium jenynsii & JA & & \\
\hline
\end{tabular}



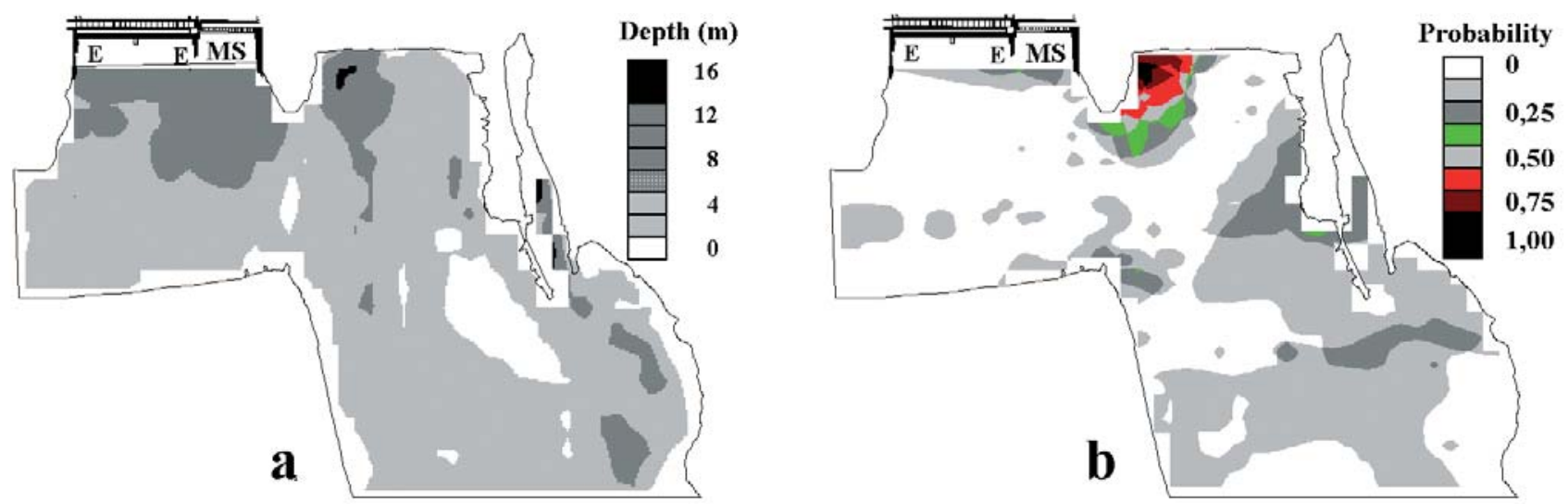

Fig. 6. a) Depth (m) distribution in the tailwater of Yacyreta Dam. b) Areas of maximum density ( $>0.2 \mathrm{fish} / \mathrm{m} 2$ ) with spillway closed. Data recorded at midday and dusk from July, 1997 to June, 1998. E - fishway entrances; MS - main spillway.

elongatus. However, large-sized species such as $P$. corruscans, Brycon orbignyanus (salmon de río), $P$. mesopotamicus and Z. jahu were not recorded (Borghetti et al., 1994), and relatively few species were able to ascend to the top of the ladder (Fernández et al., 2004). Overall, the success of fish ladders in the upper basin is sporadic and generally does not pass substantial numbers of large migratory species. Additionally, they appear ill-suited for maintaining fish stocks in cascading reservoir systems (Agostinho et al., 2004).

The dams built in or planned for Argentina, Uruguay, and Paraguay are higher and use more complex systems than the simple pool-and-weir systems found in the upper Paraná basin. For example, Aña Cua (a remote, secondary spillway for Yacyretá Dam) will feature a combination system comprised of elevators connected to the tailrace by an attraction flow channel with lateral entrances (Harza, 2001). Corpus Dam (nominal height of $38 \mathrm{~m}$ ) to be constructed upstream of Yacyretá Dam will feature a combination of a pool-and-weir channels and elevators (Castello, 1982). The three Middle Paraná dams (nominal height of $18 \mathrm{~m}$ ) were originally planned to be located downstream of the Paraguay confluence before their construction was abandoned. They were to feature a design adapted from Russian rivers (Pavlov, 1989) which included a system of elevators complemented with fish barges that could transport migrants upstream through the navigation locks (Poddubnyi et al., 1981). Finally, Borland systems were recommended for Garabi Dam (nominal height of $37 \mathrm{~m}$ ) to be constructed upstream of Salto Grande Reservoir (Boiry \& Quirós, 1985). Notably, none of these passage systems considered downstream migration of larvae, juveniles or adults. This oversight is critical because, unlike semelparous salmonids, South American iteroparus species must be able to return after spawning if their populations are to survive.

Knowledge about the design and performance of existing fish passage facilities can help designers of future systems to engineer improved systems. Oldani \& Baigún (2002) and Oldani et al. (2005a) identified the following causes of low transfer efficiency for the fish elevators at Yacyretá Dam which must be addressed in the design of future systems.

\section{a) Undersized relative to approach channel dimensions:}

Cross-sectional area of the two elevators is small compared to the attraction channel cross- section with the left and right elevators having only about $1.8 \%$ and $1.1 \%$, respectively, of the approach channel cross-sectional area.

\section{b) Undersized relative to the sizes and numbers of target species:}

The elevators are small in volume $\left(15 \mathrm{~m}^{3}\right.$ each $)$ relative to the sizes (some approach $2 \mathrm{~m}$ in length) and the numbers of target species that must be transferred. The elevators physically cannot transfer the necessary numbers of migrants to maintain viable populations of target species, particularly if non-target species clog the system.

\section{c) Inadequate cycling rate:}

The total number of fishes transferred by the system is determined by the size and cycling rate (time required to fill, raise, empty and lower) of the elevators. Under optimal conditions the elevators cannot complete more than 24 cycles per day.

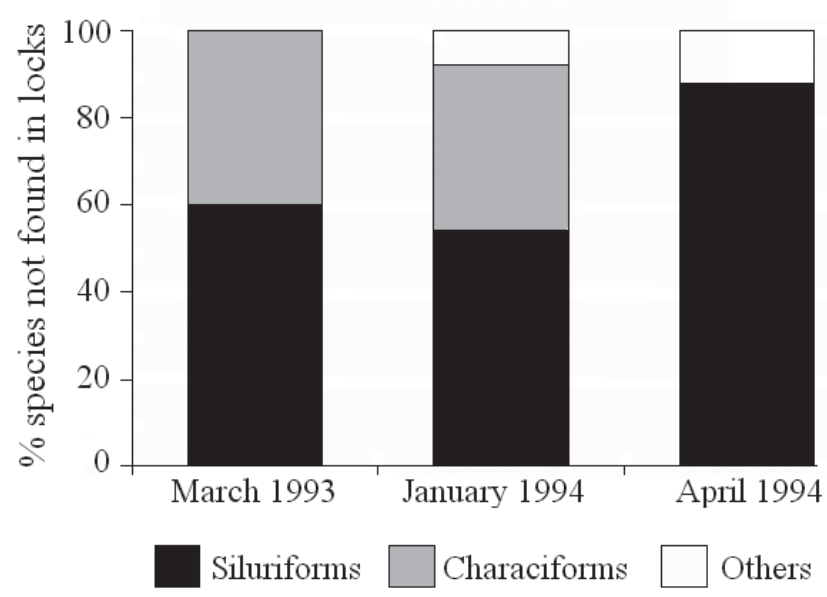

Fig. 7. Proportion of species grouped by order that were sampled in the tailrace and never sampled in the Borland locks of Salto Grande Dam. 

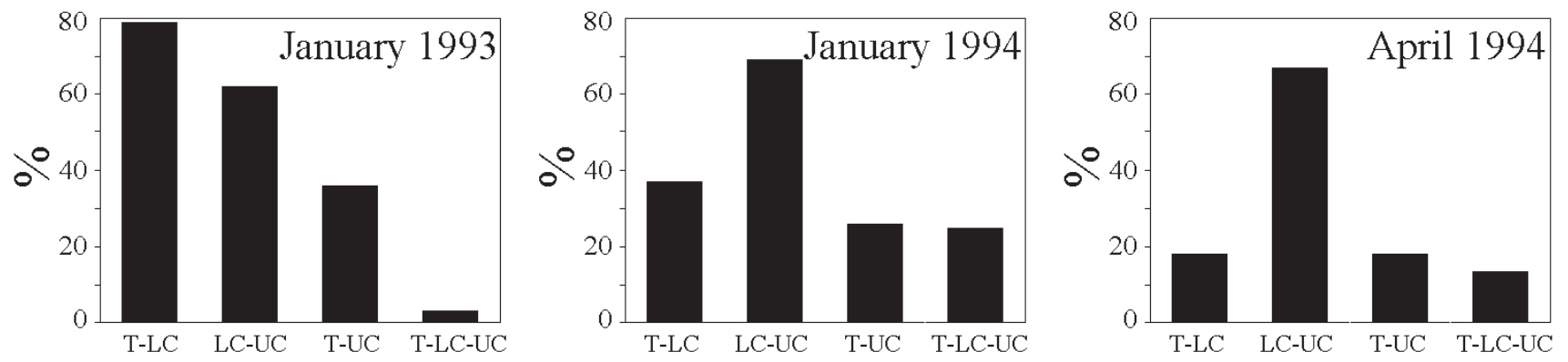

Fig. 8. Paired comparisons of species composition for the tailrace (T), lower chamber (LC) and upper chamber (UC) at different sampling periods (adapted from Espinach Ros et al., 1997).
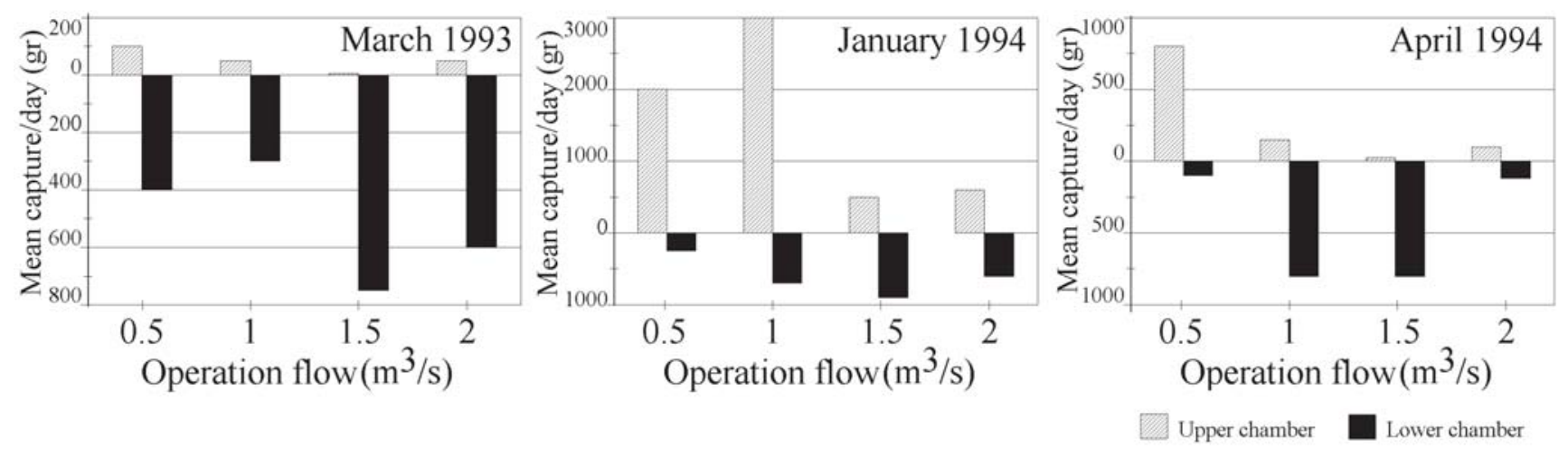

Fig. 9. Comparison between fish biomass in the upper and lower chambers across different operation flows over three different months (adapted from Espinach Ros et al., 1997).
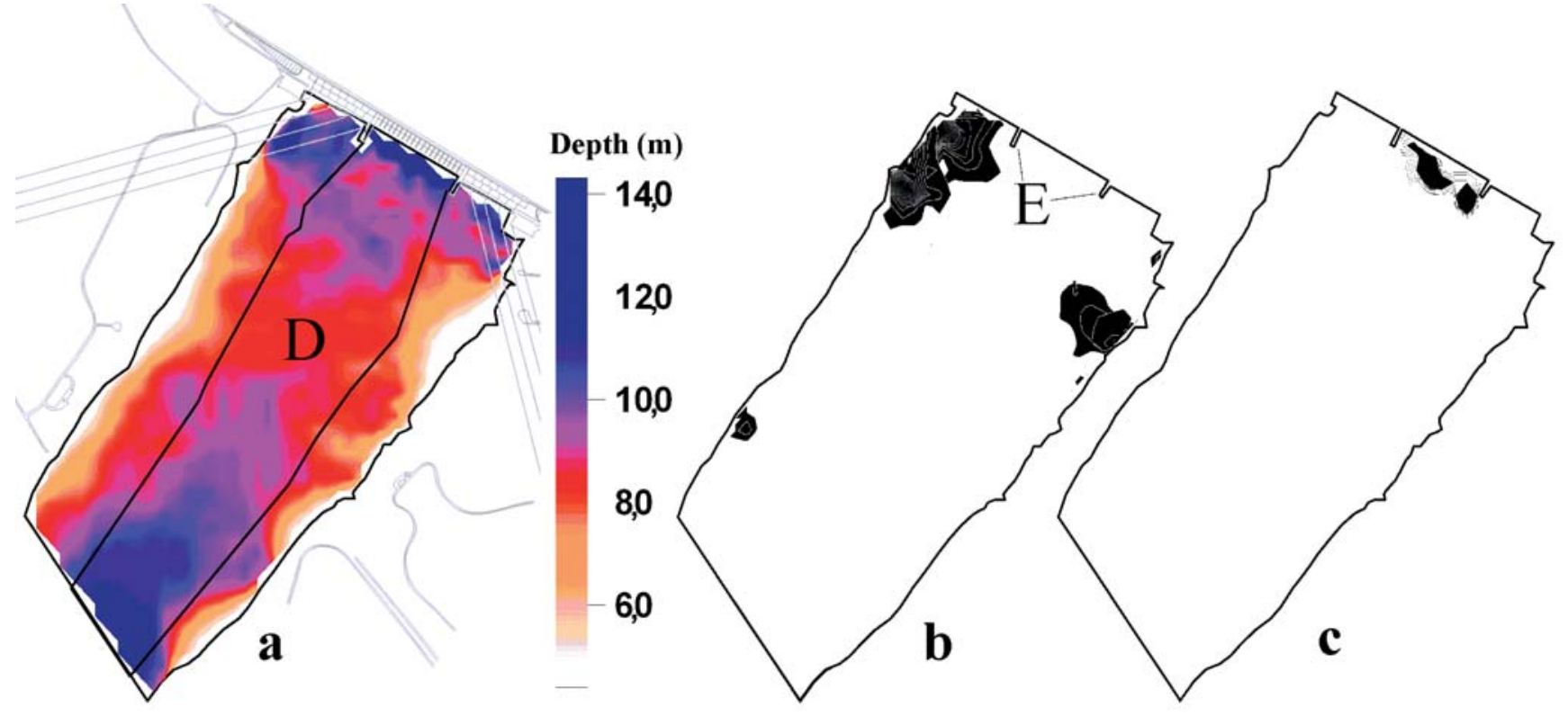

Fig. 10. Fish distribution and density in the tailwater of Salto Grande Dam. a) Depth distribution. b) Areas of maximum fish concentration (16 fish $\left./ \mathrm{m}^{2}\right)$, November, 2002, with opened spillway. c) Areas of maximum fish concentration $\left(29 \mathrm{fish} / \mathrm{m}^{2}\right)$ November, 2000, with closed spillway. D - bubble area produced by spillway. E - fishway entrances.

\section{d) Inability to exclude undesirable species:}

Some undesirable species are heavily armored with defensive spines that will injure or kill migratory species in the crowded confines of the elevator bucket. There is no way to regulate the number, species or sizes of undesirable species.
Consequently, elevator overcrowding can result in serious stress and injury to target species.

e) Elevator attracting flow drowned out by powerhouse discharges: 
Table 3. Comparison among different fish passage systems installed $\left(^{*}\right)$ or adaptable to large South America rivers.

\begin{tabular}{|c|c|c|}
\hline System & Advantages & Disadvantages \\
\hline Pool-and-weir * & Great transference capacity & $\begin{array}{l}\text { Selective for deep-water species. Susceptible to variations in } \\
\text { the water level of the reservoir. }\end{array}$ \\
\hline Elevators * & $\begin{array}{l}\text { Cost is independent on the height of the } \\
\text { dam. }\end{array}$ & $\begin{array}{l}\text { High cost of construction, operation, and maintenance. } \\
\text { Generate a high degree of stress in fish. The number of fish } \\
\text { transferred depends on the elevator's volume and cycle time. }\end{array}$ \\
\hline Locks for fish * & $\begin{array}{l}\text { Flexible design that can be adapted to } \\
\text { different types of dams. }\end{array}$ & $\begin{array}{l}\text { Low capacity for transference. The number of fish transferred } \\
\text { depends on the number of daily cycles. During the filling } \\
\text { phase, the attraction flow is either reduced or eliminated. }\end{array}$ \\
\hline Locks for navigation & Great transference capacity & $\begin{array}{l}\text { Located in places of little current and low capacity of } \\
\text { attraction. May be limited if navigation traffic is limited. }\end{array}$ \\
\hline $\begin{array}{l}\text { Mobile systems of } \\
\text { transport }\end{array}$ & $\begin{array}{l}\text { Possibility of being placed wherever } \\
\text { migratory fish are found. They are suitable } \\
\text { when other systems are not possible }\end{array}$ & Very low transfer capacity. \\
\hline $\begin{array}{l}\text { By-pass systems * } \\
\text { (artificial rivers) }\end{array}$ & Great transfer capacity & $\begin{array}{l}\text { It has low slope and great length, which makes it difficult to } \\
\text { install the entry near the dam. It is susceptible to level } \\
\text { variations at the reservoir. }\end{array}$ \\
\hline
\end{tabular}

The collector channel entrances are very close to the turbine draft tubes so that the small attracting flows exiting the elevator entrance may be masked by powerhouse discharge. Pavlov (1989) identified criteria for effective attraction flows and hydraulic characteristics within the collector channels relative to fish swimming capabilities. These criteria have not been evaluated at Yacyretá Dam.

\section{f) Elevator channel entrance not contiguous with thalweg:}

The entrance to the collection channel is separated from the main channel by a vertical sill. Consequently, thalwegoriented migratory species such as large silurids that swim near the bottom cannot locate the entrance to the transfer system. Bottom-dwelling fish appear to avoid flat vertical surfaces and instead follow gentle slopes and contours around mounds as was noted for the Acipenseridae (Pavlov, 1989).

Pavlov (1989) showed that more fish enter into the collection channel as water velocity increases. The water velocity of $0.22 \mathrm{~m}^{3} \mathrm{~s}^{-1}$ in the right collector channel is probably insufficient to attract large migratory fish to the location of the crowder because it is substantially less than the water velocity in the Parana River during migration. The reduced water velocity of the right collector channel may explain why the passage rate is reduced in the right elevator compared to the left elevator. Additionally, some of the limitations listed above are exacerbated by the mismatch between where large migratory fish concentrate in the tailwater and where passage system entrances are located (Oldani et al., 2001a). Results from the elevators at Yacyretá Dam show that they cannot be used as a design guide to develop fish passage systems for other dams in the La Plata basin without a critical analysis of passage performance.

Santa Clara Dam on the Mucuri River has a unique fish passage facility that combines an elevator with a tanker truck to transfer fish upstream (Pompeu \& Martinez, 2005). These authors estimated that about 70,000 fish were transferred in 5 months. Large migratory species were represented by Prochilodus vimboides (33\%), Leporinus conirostris $(9 \%)$ and L. steindachneri (7\%). Although not reported, we conclude passage efficiency may be low because only a mean of 106 fish per cycle was transferred and $40 \%$ of the cycles failed to transport any fish. It is not clear if low passage efficiency was caused by elevator design and operation or by the trucking phase of translocation.

Like the elevators at Yacyretá Dam, the Borland locks also have a number of design deficiencies. They can complete only a limited number of cycles in a 24 -h period because one transfer cycle takes one hour to complete. Hydraulic conditions at the entrances to the Borland locks vary considerably,

Table 4. Primary characteristics of migratory fish species of the rivers in the La Plata basin (modified from Oldani et al., 1998).

\begin{tabular}{ll}
\hline \multicolumn{1}{c}{ Characte Tables Ristic } & Grade \\
\hline Iteroparity & Common \\
Semelparity & Never \\
Anadromy & Very rare \\
Thermal niche & Euri and of mild-hot waters \\
Reproductive habits & Free spawning in open waters \\
Smoltification & Never \\
Refuge area and breeding of juveniles & Ponds of floodplain \\
Active upstream migrations of adults & Yes \\
Active downstream migrations of adults & Frequent \\
Active migrations of juveniles & Unknown \\
Spawning areas & Great rivers and their tributaries \\
Sensory basis of homing behavior & Unknown \\
Tolerance to low oxygen levels during migrations & High \\
Response to changes in water level and temperature during migrations & Yes \\
\hline
\end{tabular}


depending upon operation of the powerhouse and spillway and tailrace elevations (Oldani \& Leites, 2001; Oldani et al., 2001a, Oldani et al., 2001b; Oldani et al., 2005b; Ríos et al., 1997). For example, the proper operation of the locks is hindered when the reservoir elevation is less than $33 \mathrm{~m}$ or more than $35 \mathrm{~m}$ above the tailrace elevation or under certain spillway operations (Delfino et al., 1986). Differences in optimum attraction flow between upper and lower chambers further reinforces the concept that water level at the reservoir and tailrace may substantially affect lock efficiency. Quirós (1988) noted that the operating limit for the upper lock was $9.20 \mathrm{~m}$, which is associated with a reservoir inflow of $7,280 \mathrm{~m}^{3} \mathrm{~s}^{-1}$. This water elevation is common during the September to October fish migration period so that the Borland locks are often inoperable when they are most needed. Acoustic surveys in the tailrace indicate that fish are unable to locate entrances to the locks when the spillway is closed probably because the powerhouse discharge $\left(9800 \mathrm{~m}^{3} \mathrm{~s}^{-1}\right)$ drowns out the small attraction flows $\left(0.5-2.0 \mathrm{~m}^{3} \mathrm{~s}^{-1}\right)$ at the $1.0-\mathrm{m}$ wide lock entrances on the $375 \mathrm{~m}$ wide spillway (Quirós, 1988). Conditions improved only a little when the spillway is open because water velocities may exceed the swimming speed of most fish species. Pavlov (1989) states that attracting water velocity should be no greater than 0.6-0.8 times the critical fish swimming speed and that the collector channel water velocities should not exceed the fish cruising speed.

These findings about fish elevators at Yacyretá and Santa Clara dams and Borland locks at Salto Grande are important for the future of fish passage design and reservoir construction in the lower La Plata River basin. Most of the planned reservoirs will either feature elevators by themselves or in combination with other designs. For example, elevator-based designs have been proposed for 10 dams in Minas Gerais state alone (Pompeu \& Martinez, 2005). The Borland locks at Salto Grande Dam have many of the same limitations as the Yacyretá elevators so that similar design improvements for the locks should be considered as those listed above for the elevators. The Borland locks should be considered with caution even in smaller rivers or in settings where upstream breeding areas are still available after dam closure. The limitations we observed for the Salto Grande lock and pointed out by Larinier and Marmulla (2003) for other rivers include: limited number of cycles in a 24-h period, sensitivity to powerhouse and spillway operation, and sensitivity to upstream and downstream water levels.

Many of the problems exhibited by existing South American fish passage systems can be traced to the North American origin of their designs and associated salmon focus. Development of standard designs suitable for South American rivers and fish species is a wise investment because fish passage systems are typically an integral part of the dam, and inadequate systems cannot be modified without extensive cost and effort. Some design parameters for South American systems can be inferred from the scientific literature. Close proximity of the fishway entrances to dam outlets is appropriate for salmonids (Rochester et al., 1984; Clay 1995). How- ever, salmonids typically inhabit high-gradient streams and are suited for navigating through the highly turbulent flows of tailraces to find bypass entrances. However, the lower La Plata River basin has a lower gradient, potamic riverscape. Fish evolved in such a system may be unable to locate small attraction flows against a background of high powerhouse and spillway flows (Larinier, 2001). For example, sturgeon often accumulate in eddies in tailwaters (Pavlov, 1989) whereas salmon typically are in the high-energy flow fields near the dam searching for upstream passage. These differences in behavior may be related to differences in motivation to spawn between semelparous salmonids and other iteroparous species (Crespi \& Teo, 2002). Iteroparous species differ in several characteristics (Table 4). Such species may be more likely to abandon their migration in the complex, high-energy hydraulic patterns in tailraces to migrate in a succeeding year, whereas semelpalrous species must "migrate at all costs" because their death will ensue at the end of the migration period and their only opportunity for procreation will be lost.

The low efficiency of existing fish passage systems indicates that present fishery management strategies in the $\mathrm{La}$ Plata River basin to conserve the unique ichthyofauna of South America are inadequate. The general ecological data produced by classic South American studies of fish migrations in unregulated systems are insufficient to design efficient fish passage systems. Data from new bioengineering studies are needed to develop hydraulic design criteria that can be applied to the unique migratory fishes of South America. Unfortunately, we are unaware of any studies in South America focused on the following critical research needs: fish swimming capabilities, hydrodynamic characteristics of different fishway systems, and the hydrodynamic cues used by fish to either select their swim path to upstream spawning areas or their return to adult habitat. Clearly a new direction for fish passage design is required if the unique South American ichthyfauna is to be conserved. Hydrodynamic cues used by fish to select their migration path should be a critical component of fish passage designs, but, unfortunately, no studies are available or ongoing to develop such information.

A major factor in the poor performance of fish passage systems in the existing dams in the lower La Plata River basin is a lack of appreciation of the scale and magnitude of the studies needed to protect this valuable resource. For example, little information about the ichthyofauna was collected prior to dam design and construction at either Yacyretá or Salto Grande. The information that was collected was limited in spatial scale, typically concentrated on the dam site, and ignored the extensive upstream and downstream effects of impoundment. Also, post-impoundment information on fish passage performance is generally limited in spatial and temporal resolution so that study results are arguable and cannot conclusively lead to robust assessment of impact or system improvements. At the Yacyretá elevators, for example, system assessment is based solely on visual estimates of fish usage at the elevators. Studies are not considered that 
could improve the performance of the system by modifying attraction flows or by creating better light conditions within the collector channel. Similarly, information describing the performance of the Borland locks at Salto Grande is collected only intermittently.

Fish passage should be considered as one element in the broader context of ecosystem management for sustainable fisheries because efficient upstream fish passage facilities by themselves will not guarantee sustainable fish stocks due to the broader effects of regulation. Moreover, the challenge of preserving migratory species in large rivers of the lower $\mathrm{La}$ Plata River basin is made more complex by the life history of South American fishes. For example, downstream passage of post-spawning adults is not considered in the design of dams even though migratory South American fishes are generally iteroparous (Oldani et al., 1998; Agostinho et al., 2002). Passive drift of larvae, active downstream migration of juveniles, and the survival rates of each through dam outlets are also unknown. Based on North American experiences, downstream passage survival may vary considerably depending upon differences in elevation between upstream and downstream and design and operation of the outlet works. Even if fish are able to successfully pass the dam, successful reproduction may not occur if spawning and rearing areas have been inundated by impoundment, since most of species select the thalweg or main tributaries. These broader issues require inputs from fishery managers, stakeholders, anglers, NGO's, economists, and social scientists to ensure that all ecological and socio-economic factors are considered when designing fish passage systems.

At best, the factors identified above may be sufficiently benign that genetic exchange may be adequate for some species for some years. At worst, some or all of the factors may be sufficiently severe that together they cause upstream populations to be completely isolated from downstream populations. Closure of Salto Grande Dam on the Uruguay River in 1984 resulted in a substantial decrease in abundance of many downstream species and changes in the fish community structure in the upstream reservoir. Dam closure either isolated or inundated critical reproduction and breeding areas preventing migratory species from completing their life cycle (Espinach Ros \& Chediak, 1999).

The effects of inadequate fish passage at Yacyretá Dam extend to the reservoir fishery. Prior to over-exploitation and impoundment, migratory fish populations in the rivers of the lower region of the La Plata basin were abundant and supported an economically significant fishery (Quirós \& Cuch, 1989; Oldani et al., 1992; Oldani, 1994; Oldani et al., 2005a). However, fishery yield within the Yacyretá reservoir has been reduced to an estimated $14 \mathrm{~kg} / \mathrm{ha}$ (Petrere et al., 1998). Ten years after filling, the reservoir fishery is dominated by a few species such as Hemiodus orthonops (sardina), Pachyurus bonariensis (corvina de río) and Trachydoras paraguayensis (armado), along with a concomitant reduction in migratory species (Roa et al., 2000; Roa \& Permingeat, 2001). Pachyurus bonariensis, a species uncommon in the fishery prior to im- poundment, is now one of the most abundant species in the reservoir fishery (De Lucia, Roncati \& Roa, unpublished data), and the harvest of P. corruscans, Z. jahu, P. mesopotamicus, S. brasiliensis and B. orbignyanus has been reduced by $90 \%$ (Baigún, unpublished data).

The effects of inadequate fish passage at Yacyretá Dam also have a regional impact on Paraná River fisheries. Fernández et al. (2004) noted the low abundance of large migratory species downstream of Itaipu Dam, the next dam upstream of Yacyretá Dam. Consequently, fish conservation mitigation possibilities are reduced at Itaipu Dam. Similar impacts on the regional fish community have been described for Salto Grande (Delfino \& Baigún, 1991; Delfino et al., 1994) and for Brazilian reservoirs that lack effective fish passage facilities. For example, fish yield was only $9 \mathrm{~kg} / \mathrm{ha}$ within Brazilian reservoirs with the highest yield occurring in those reservoirs characterized by upriver fluvial sections (Gomes \& Miranda, 2001). Migratory species represented only 5\% of the commercial catch in the following six reservoirs located in the upper Paraná basin: Jupia, Itaipu, Agua Vermelha, Barra Bonita, Ibitinga, Promissão and Nova Avanhandava (Agostinho, 1994)

Many key questions remain about fish passage systems in the lower La Plata River basin. For example, what proportion of the downstream population should be transferred upstream for each species? Should the passage target for South American populations follow management practices in other countries such as Russia where maximum elevator efficiency is $10 \%$ for non-salmonid species? What is the fate of transferred fish species when upstream spawning and hatching areas are inundated by the reservoir? Does the upstream reservoir provide the necessary hydrodynamic cues for reproductively ready fish to locate upstream spawning sites (if they have not been inundated or destroyed)? What are the best fish passage designs that can effectively pass the many different migratory species occurring in South America? How should fish passage be implemented in a river system that crosses international boundaries? How should fish passage be planned when some dams have passage facilities and others do not? For example, Salto Grande Dam on the Uruguay River has Borland fishways, and a similar system is planned for the proposed upstream Garabi Dam. However, there are no fishways upstream of Itá Dam and Machadinho Dam on the Uruguay River in Brazil.

We conclude that the construction of hydroelectric dams in the La Plata River basin has had a substantial adverse impact on the ichthyofauna, particularly the large migratory species that have significant commercial and recreation value and ecological importance. The present rates of environmental modification by dams and lack of effective mitigation are not sustainable and will result in the continued depletion of the iconic, large migratory fishes of South America. Present knowledge about fish passage design for South American dams is still insufficient to preserve migratory fish. Realistically, it is unlikely that the diverse and unique ichthyofauna of South America can ever be fully restored to 
preimpoundment levels because of irreversible changes caused by impoundment and land use changes within the basin. However, we believe that improvements in fish passage design and better understanding of the behavior and environmental requirements of these species could maintain sustainable population numbers. We urge the international organizations that fund the planning and construction of dams to do more than allot the modest funding to conduct short-term, small-scale studies near the dam site. It is necessary that fishery agencies in the La Plata River basin coordinate the study and management of this valuable resource and consider water management policies at a basin level in regulated rivers, if migratory fish are to be preserved.

\section{Acknowledgments}

We acknowledge Luiz Malabarba for reviewing and updating fish species nomenclature.

\section{Literature Cited}

Agostinho, A. A. 1994. Pesquisas, monitoramento e manejo da fauna aquática em emprendimentos hidrelétricos. In: Seminário sobre fauna aquática e o setor elétrico brasileiro. Reuniões temáticas preparatórias, 1993. Rio de Janeiro-RJ: Eletrobrás: COMASE. p. 38-59. (Caderno 1: Fundamentos).

Agostinho, A. A. \& L. C. Gomes. 1997. Manejo e monitoramento de recursos pesqueiros: perspectivas para o reservatório de Segredo. Pp. 319-364. In: Agostinho, A. A. \& L. C. Gomes (Org.). Resevatório de Segredo: bases ecológicas para o manejo. Maringá, PR, 386p.

Agostinho, A. A., L. C. Gomes, D. R. Fernandez \& H. I. Suzuki. 2002. Efficiency of fish ladders for Neotropical icthyofauna. River Research and Application, 18: 299-306.

Agostinho, A. A., L. C. Gomes \& J. D. Latini. 2004. Fisheries management in Brazilian reservoirs: lessons from/for South America. Interciencia, 29: 334-338.

Agostinho, A. A., L. C. Gomes, S. Veríssimo \& E. K. Okada. 2004. Flood regime, dam regulation and fish in the Upper Paraná River: effects on assemblage attributes, reproduction and recruitment. Reviews in Fish Biology and Fisheries, 14:11-19.

Agostinho, A. A., S. M. Thomaz, C. V. Minte-Vera \& K. O. Winemiller. 2000. Biodiversity in the high Paraná River floodplain. Pp. 89118. In: Gopal, B., W. J. Junk, J. A. Davis (Eds.). Biodiversity in wetlands assessment function and conservation, v. 1, Leiden, The Netherlands. Backhuys Publishers, 353p.

Bayley, P. 1973. Studies on the migratory characin Prochilodus platensis Holmberg 1888 (Pisces, Characoidei) in the river Pilcomayo, South America. Journal of Fish Biology, 5: 25-40.

Boiry, L \& R. Quirós. 1985. Medidas tendientes a la protección de la ictiofauna del río Uruguay de los efectos de construcción de la represa de Garabí. São Paulo, Brasil, Buenos Aires, Argentina HIDRENED-HIDROSERVICE, Água y Energía Eléctrica, Eletrobrás, 91p.

Bonetto, A. A. 1963. Investigaciones sobre migraciones de peces en los ríos de la cuenca del Plata. Ciencia e Investigación (Buenos Aires), 19(1-2): 12-25.

Bonetto, A. A. 1986. The Paraná River system. Pp. 541-556. In: Davies, B. R. \& K. F. Walker (Eds.). The Ecology of River System. Dordrecht, The Netherlands, Dr W. Junk Publisher, 574p.
Borghetti, J. R., V. S. G. Nogueira, N. R. B. Borghetti \& C. Canzi. 1994. The fish ladder at the Itaipu Binacional hydroelectric complex on the Paraná river, Brazil. Regulated Rivers: Research and Management, 9:129-130.

Bowen, M. D, S. Marques, L. G. M. Silva, V. Vono \& H. P. Godinho. 2006. Comparing on site human and video counts at Igarapava fish ladder, South Eastern Brazil. Neotropical Ichthyology, 4:291-294.

Cada, G. F. \& M. J. Sale. 1993. Status of fish passage facilities at non federal hydropower Projects. Fisheries, 18:4-12.

Capeleti, A. R. \& M. Petrere Jr. 2006. Migration of the curimbata Prochilodus lineatus (Valenciennes, 1836) (Pisces Prochilodontidae) at the waterfall "Cachoeira de Emas" of the Mogi-Guaçu River, São Paulo, Brazil. Brazilian Journal of Biology, 66(2):651659.

Carolsfeld, J, B. Harvey, C. Ross \& A. Baer (Eds.). 2004. Migratory fishes of South America. Biology, fisheries and conservation status. Ottawa, Canada, World Fisheries Trust/World Bank/ IDRC, 372p.

CARU, CTMSG, INAPE, INIDEP. 1994. Monitoreo del funcionamiento del sistema de transferencia de peces de la represa de Salto Grande. Informe Anual del Programa de Conservación de la Fauna Ictica en el embalse de Salto Grande (Parte 2), Publicación de la Comisión Administradora del Río Uruguay y la Comisión Técnica Mixta de Salto Grande, 81p.

Castello, H. P. 1982. Biología y migraciones de la fauna de peces del río Alto Paraná, Buenos Aires, Asunción, Comisión Mixta Argentino Paraguaya del Río Paraná, 110p.

Clay, C. 1995. Design of fishways and other fish facilities. Second Edition. CRC Press Boca Raton, Florida, 247p.

Colin, R. 1997. Examples of World Bank projects where impact mitigation is part of project implementation in integrating freshwater biodiversity. Conservation with development: Some emerging lessons. World Bank Environmental Department 61, $12 \mathrm{p}$.

Crespi, B. J. \& R. Teo. 2002. Comparative phylogenetic analysis of the evolution of semelparity and life history in salmonid fishes. Internacional Journal of Organic Evolution, 56:1008-1020.

Delfino, R., F. Amestoy, S., Sverlij, M. Spinetti, A. Espinach Ros, R. Foti, G. Chediak. \& M. Bellagamba. 1994. Estructura de las comunidades de peces. Pp. 4-15. In: Espinach Ros, A. \& G. C. Ríos Parodi (Eds.). Conservación de la fauna íctica en el embalse de Salto Grande. Publicación de la Comisión Administradora del Río Uruguay y la Comisión Técnica Mixta de Salto Grande, 37p.

Delfino, R. \& C. Baigún, 1985. Marcaciones de peces en el embalse de Salto Grande, Río Uruguay (Argentina-Uruguay). Revista de la Asociación de Ciencias Naturales del Litoral, 16(1):85-93.

Delfino, R. \& C. Baigún. 1991. Cambios en la comunidad de peces en el embalse de Salto Grande. Pp. 110-117. In: I. Vila (Ed.) Segundo simposio internacional de ecología de peces de lagos y embalses. FAO COPESCAL, Documento Técnico 9:7-30.

Delfino, R., C. Baigún \& R. Quirós. 1986. Esclusas de peces en la represa de Salto Grande. Consideraciones acerca de su funcionamiento. Informes Técnicos del Departamento de Aguas Continentales $\mathrm{N}^{\circ}$ 3, Mar del Plata, Argentina, Instituto Nacional de Investigación y Desarrollo Pesquero, 55p.

Espinach Ros, A., F. Amestoy, R. Delfino, S. Sverlij, R. Foti, M. Spinetti \& G. Chediak. 1997. Monitoreo del funcionamiento del sistema de transferencia de peces. Pp. 15-26. In: Espinach Ros, A. \& C. Ríos (Eds.). Conservación de la fauna íctica en el embalse de Salto Grande. Comisión Administradora del Río Uruguay-CARU, 37p. 
Espinach Ros, A. \& G. Chediak. 1999. Migraciones de peces en el río Uruguay. Pp. 13-14. In: Primeras jornadas sobre conservación de la fauna íctica en el río Uruguay. Comisión Administradora del Río Uruguay-CARU, 52p.

Espinach Ros, A., S. Sverlij, F. Amestoy \& M. Spinetti. 1998. Migration pattern of the sábalo Prochilodus lineatus (Pisces, Prochilodontidae) tagged in the lower Uruguay River. Verhandlung International Verein Limnology, 26:2234-2236.

Fernandez, D. R., A. A. Agostinho \& L. M. Bini. 2004. Selection of an experimental fish ladder located at the dam of the Itaipu Binacional, Paraná River, Brazil. Brazilian Archives of Biology and Technology, 47:579-586.

García, J. O. 1999. Principales características de la central hidroeléctrica de Yacyretá, Argentina y de los ambientes de su área de influencia en relación con los programas de evaluación de la fauna íctica. Revista de Ictiología, 7: 5-14.

Godinho, H. P., A. L. Godinho, P. S. Formagio \& V. C. Torquato. 1991. Fish ladder efficiency in a southeastern brazilian river. Ciência e Cultura, 43(1):63-67.

Godoy, M. P. 1975. Peixes do Brasil sub-ordem Characoidei - Bacia do rio Moji-Guaçu, Piracicaba, Franciscana, 4v, 846p.

Godoy, M. P. 1985. Aquicultura. Atividade multidisciplinar. Escadas e outras facilidades para passagens de peixes. Estações de piscicultura. Florianópolis, SC, Eletrosul-Eletrobrás, 77p.

Gomes, L. C. \& L. E. Miranda. 2001. Riverine characteristics dictate composition of fish assemblages and limit fisheries in reservoirs of the upper Paraná River basin. Regulated Rivers Research and Management, 17:67-76.

Harza y Asociados. 2001. Central del Brazo Aña Cua. Sistema de transferencia de peces. Memoria Descriptiva: Harza y Asociados, 3p.

Junk, W. J., P. B. Bayley \& R. E. Sparks. 1989. The flood pulse concept in river-floodplain systems. Canadian Special Publication of Fisheries and Aquatic Sciences, 106:110-127.

Larinier, M. 2001. Environmental issues, dams and fish migrations. Pp: 45-90. In: G. Marmulla (Ed.) Dams, fish and fisheries. Opportunities, challenges and conflict resolution. FAO Fisheries Technical Paper. n. 419, 166p.

Larinier, M. \& G. Marmulla. 2003. Fish passes, types, principles and geographical distribution. An Overview. Pp: 183-206. In: R. L. Welcomme \& T. Petr (Eds.). Proceedings of the Second International Symposium on the Management of Large Rivers for Fisheries Volume II. FAO Regional Office for Asia and the Pacific, Bangkok, Thailand. RAP Publication 2004/17, 357p.

Leites, V. 1999. Esclusa para peces de la represa de Salto Grande. In: Primeras Jornadas sobre conservación de la fauna íctica del río Uruguay. Comisión Administradora del Río Uruguay (CARU), Paysandú, 22-23 de noviembre de 1999: 21-25.

Makrakis, M., S. Makrakis, D. Baumgartner, G. Baumgartner, D. Fernández, W. Morris \& O. García. 2002. Study of fish migration in the Paraná River. In: Proceedings of the International Symposium on reservoir management in tropical and subtropical regions, Sept 26, 2002, Foz do Iguaçu, Brazil:ICOLDInternational Comission on Large Dam, p.519-531.

Odeh, M. 1999. Innovations in fish passage technology. American Fisheries Society, Bethesda, Maryland, 209p.

Odeh, M. 2000. Advances in fish passage technology. Engineering design and biological evaluation. Bethesda, Maryland, American Fisheries Society, 154p.

Okada, E. K., A. A. Agostinho \& M. Petrere Jr. 1996. Catch and effort data and the management of the commercial fisheries of Itaipú reservoir in the upper Paraná River, Brazil: Pp. 161-164.
In: Cowx, I. (Ed.). Stock assessment in inland water fisheries. London, Fishing New Books, 513p.

Oldani, N. O. 1990. Variaciones de la abundancia de peces del valle del río Paraná. Revue D’Hydrobiologíe tropicale, 23(1):67-76.

Oldani, N.O. 1994. General considerations on productivity of fish in the Paraná River. In: International Workshop on Regional Approaches to Reservoir Development and Management in La Plata River Basin. Proceedings of the environmental and social dimensions of reservoir development and management in the La Plata River basin, Aug 1991. Nagoya, Japan: UNCRD: 59-65 (UNVRD Research Report Series, 4).

Oldani, N. O. \& C. Baigún. 2002. Performance of a fishway system in a major South American dam on the Paraná river (ArgentinaParaguay). River Research and Applications, 18:171-183.

Oldani, N. O., C. Baigún \& R. Delfino. 1998. Fishway performances in South American regulated rivers. In: Hayes, D. F. (Ed.). Engineering Approaches to Ecosystem Restoration. Proceeding of the Wetlands Engineering and River Restoration Conference, March 22-27, 1998, Denver, CO: ASCE American Society of Civil Engineers: 1129-1134.

Oldani, N. O, C. Baigún \& R. Delfino. 2005a. Consideraciones sobre los sistemas de transferencia para peces en las represas de los grandes ríos de la cuenca del Plata en la Argentina. Pp.36381. In: F. G. Aceñolaza (coordinador). Temas de la Biodiversidad del litoral fluvial argentino II. INSUGEO, Misceláneas, 14, 550p.

Oldani, N. O., C. Baigún, R. Delfino \& R. Rodríguez. $2001 \mathrm{a}$. Evaluación de los sistemas de transferencia para peces de la represa de Yacyretá. Natura Neotropicalis, 32(2):87-100.

Oldani, N. O., J. Iwaszkiw, O. Padín \& A. Otaegui. 1992. Fluctuaciones de la abundancia de peces en el alto Paraná (Corrientes, Argentina). Actas del II Seminario El río Uruguay y sus recursos, 1(1):43-53.

Oldani, N. O. \& V. Leites. 2001. Evaluación de la abundancia y distribución de peces aguas abajo de la represa de Salto Grande (río Uruguay). In: Seminario Internacional Gestión Ambiental e Hidroelectricidad, 19-21 de septiembre 2001, Concordia, - Argentina: Comisión Técnica Mixta de Salto Grande. Media digital.

Oldani, N. O., A. Madirolas, A. Cabreira, V. Leites \& M. Bellagamba. 2002. Abundancia y distribución de peces aguas abajo de la represa de Salto Grande (río Uruguay). Informe Técnico, noviembre $2002,17 \mathrm{p}$.

Oldani, N. O., P. Minotti, R. Rodríguez, R. Delfino \& C. Baigún. 2001b. Incidencia de los principales factores ambientales en la abundancia y distribución de los peces del río Paraná aguas abajo de Yacyretá. Natura Neotropicalis, 32(1):41-48.

Oldani, N. O., A. Otaegui, V. Leites, R. Rodríguez \& C. Baigún. 2005b. Evaluación del sistema de transferencia de peces de la represa de Salto Grande (río Uruguay). In: Actas del IV Taller Internacional Sobre Enfoques Regionales para el Desarrollo y Gestión de Embalses en la Cuenca del Plata, 29 de noviembre al 2 de diciembre de 2005. Salto Grande, Argentina-Uruguay. Universidad de Nihon (Japón) y Programa Mundial de Evaluación de los Recursos Hídricos (WWAP).

Pavlov, D. S. 1989. Structures assisting the migrations of non salmonid fish. USSR, Food and Agriculture Organization of the United Nations Rome, FAO Fisheries Technical Papers, (308). 97p.

Petrere Jr. M. 1985. Migraciones de peces de agua dulces en América Latina: algunos comentarios. COPESCAL Documento Ocasional $1,17 \mathrm{p}$.

Petrere Jr, M., A. A. Agostinho, A. Espinach Ros \& F. G. Vera. 1998. Evaluación del potencial pesquero en el embalse Yacyretá. Aspectos ambientales y económicos. VIII Panel de expertos 
medio ambiente y reasentamiento. Entidad Binacional Yacyretá, $19 \mathrm{p}$.

Petrere Jr., M., A. A. Agostinho, E. K. Okada, \& H. F. Julio Jr. 2002. Review of the Fisheries in the Brazilian Portion of the Paraná/Pantanal Basin. Pp. 123-143. In: Cowx, I. G. (Ed.). Management and Ecology of Lake and Reservoir Fisheries. London. Fishing News Book, 416 p.

Petts, G. E. 1990. Regulation of large rivers: problems and possibilities for environmentally-sound river development in South America. Interciencia, 15:388-395.

Poddubnyi, A. G., A. Espinach Ros \& N. Oldani. 1981. Recursos ícticos del Paraná Medio en relación con la construcción de obras hidráulicas. (Memorias y recomendaciones). Informe Técnico Agua Energía Gerencia Estudios y proyectos Paraná Medio, Santa Fe (Argentina), 105p.

Pompeu, P. dos S. \& C. B. Martínez. 2005. Estabelecimento da regra operativa de um mecanismo de transposição do tipo elevador como caminhão-tanque. Revista Brasileira de Recursos Hídricos, 10:31-42.

Pompeu, P. dos S. \& C. B. Martínez. 2006. Temporal patterns of fish passage in Santa Clara Power Plant's fish lift, Mucuri River, East Brazil. Revista Brasileira de Zoologia, 23:340-349.

Quirós, R., 1988, Estructuras para asistir a los peces no salmoídeos en sus migraciones: América Latina FAO COPESCAL Doc. TÉC., 5: 50p.

Quirós R. \& S. Cuch. 1989. The fisheries and limnology of the Lower Plata Basin. In: Dodge, D. P. (Ed.). Proc. International Large River Symposium (LARS) (Honey Harbour, Ontario, Canada, September 14-21, 1986). Ottawa:Department of Fisheries and Oceans, 1989. p. 429-443. (Canadian Special Publication of Fisheries and Aquatic Sciences, v.106).

Quirós, R., J. Bechara \& M. Insaurralde. 2000. Evaluación de sistemas de transferencia para peces en la central del Brazo Aña Cua. Informe de Avance, 51p.

Ríos, C., C. Fuentes, H. Nion, A. Espinach Ros \& G. Chediak. 1997. Área de Cría. Pp.33-36. In: Conservación de la Fauna Ictica en el embalse de Salto Grande, Comisión Administradora del Río Uruguay y Comisión Técnica Mixta de Salto Grande, $84 \mathrm{p}$.

Roa, B. H., I. M. Hirt, P. Araya, S. Flores, H. Roncati, A. Lucia \& D. R. Aichino. 2000. Informe final sobre la campaña de pesca experimental en el Río Paraná entre las progresivas 1478 (Toma de agua ERIDAY) y km. 1625 (Arroyo Yabebiri)-Argentina. Misiones, Argentina, Entidad Binacinal de Yacyretá-Universidad Nacional de Misiones, 139p.
Roa, B. H. \& E. D. Permigeat. 1999. Composición y abundancia de la fauna íctica en dos estaciones de muestreo del embalse de Yacyretá, Argentina. Revista de Ictiología, 7: 49-57.

Rochester, H. Jr., T. Loyd \& M. Farr. 1984. Impacts of small-scale hydroelectric facilites on fish and wildlife and their habitats. U.S. Fish and Wildlife Service FWS/OBS/84, 337p.

Roncati, H. A., J. A. Bechara, J. P. Roux \& A. González. 2000. Monitoreo y evaluación de la fauna íctica transferida por la instalaciones para peces de la central hidroeléctrica de YacyretáCHY. Posadas, Misiones, Argentina, Entidad Binacinal de Yacyretá-Universidad Nacional del Nordeste-Universidad Nacional de Misiones, 103p.

Roncati, H. A., J. A. Bechara, J. P. Roux \& A. González. 2001. Monitoreo y evaluación de la fauna íctica transferida por la instalaciones para peces de la central hidroeléctrica de YacyretáCHY. Posadas, Misiones, Argentina, Entidad Binacional de Yacyretá-Universidad Nacional del Nordeste-Universidad Nacional de Misiones, 141p.

Sugunan, V. V. 1997. Fisheries management of small water bodies in seven countries in Africa, Asia and Latin America. Roma, FAO Circular No 933, 149p.

Sverlij, S. B., A. Espinach Ros \& G. Orti. 1993. Sinopsis de los datos biológicos y pesqueros del sábalo Prochilodus lineatus (Valenciennes, 1847). FAO, Sinopsis sobre la pesca, $\mathrm{N}^{\circ} 154$, $64 \mathrm{p}$.

Tablado, A. N. \& N. O. Oldani. 1984. Consideraciones generales sobre las migraciones de peces del río Paraná. Boletín de la Asociación de Ciencias Naturales del Litoral, 4:31-34.

Tablado, A., N. O. Oldani, L. Ulibarrie \& C. Pignalberi de Hassan. 1988. Cambios estacionales de la densidad de peces en una laguna del valle aluvial del río Paraná (Argentina). Revue Hydrobiologie tropicale, 21(4):335-348.

Vazzoler, A. E. A. M., M. A. Lizama \& P. Inada. 1997. Influências ambientais sobre sazonalidade reprodutiva. Pp. 267-279. In: Vazzoler, A. E. A. M.; A. A. Agostinho \& N. S. Hahn (Eds.). A planície de inundação do alto río Paraná: aspectos físicos, biológicos e socioeconômicos. Editora da Universidade Estadual de Maringá, 460p.

World Commission on Dams. 2000. Dams and Development. A new framework for decision making. London, Earthscan Publ. Ltd., 404p.

Received January 2007 Accepted June 2007 